\title{
Beauty and ugliness in Olmec monumental sculpture
}

\section{Claude-François Baudez}

\section{(2) OpenEdition \\ 1 Journals}

Electronic version

URL: https://journals.openedition.org/jsa/12294

DOI: 10.4000/jsa.12294

ISSN: 1957-7842

\section{Publisher}

Société des américanistes

\section{Printed version}

Date of publication: 31 December 2012

Number of pages: 7-31

ISSN: 0037-9174

\section{Electronic reference}

Claude-François Baudez, "Beauty and ugliness in Olmec monumental sculpture", Journal de la Société des américanistes [Online], 98-2 | 2012, Online since 10 December 2015, connection on 02 September 2022. URL: http://journals.openedition.org/jsa/12294 ; DOI: https://doi.org/10.4000/jsa. 12294 


\title{
BEAUTY AND UGLINESS \\ IN OLMEC MONUMENTAL SCULPTURE
}

\author{
Claude-François BAUDEZ *
}

Since our Western art tradition has put such a prize on naturalism, we tend to think that other civilizations valued it as much as we did and do. I contend that Olmec monumental art illustrates the opposite, and suggest that the Olmecs most appreciated the anthropomorphic statues that incorporated feline features, and disliked the very naturalistic style of the colossal heads. The latter represented the severed heads of opponents who probably were losers in ritual battles. Therefore they could not claim the divine patronage of the jaguar, and had to appear just as " plain », ugly people. [Key words: olmec sculpture, colossal heads, naturalism, beauty, ugliness.]

Du beau et du laid dans la statuaire monumentale olmèque. Dans la mesure où l'art occidental a toujours valorisé le naturalisme, nous avons tendance à penser que cette appréciation a été universelle. Je soutiens ici que l'art monumental olmèque illustre le contraire et suggère que les Olmèques appréciaient les statues anthropomorphes qui intégraient des traits félins, mais n'aimaient pas le style très naturaliste des têtes colossales. Celles-ci représentaient les têtes coupées de rivaux malheureux aux batailles rituelles. Pour cela, elles ne pouvaient se réclamer du divin patronage du jaguar, et devaient se contenter de représenter des gens quelconques, sans beauté. [Mots-clés: statuaire olmèque, têtes colossales, naturalisme, beau, laid.]

De lo bello y de lo feo en las esculturas monumentales olmecas. Ya que el arte occidental ha siempre valorado el naturalismo, tenemos tendencia a creer que esta apreciación ha sido universal. Aquí sostengo que el arte monumental olmeca refleja lo contrario. Propongo que los olmecas apreciaban las estatuas antropomorfas que incorporaban rasgos del jaguar y despreciaban el estilo muy naturalista de las cabezas colosales. Estas últimas representaban las cabezas cortadas de adversarios vencidos en batallas rituales. Por esa razón no podían pretender al patrocinio divino del felino, y debían conformarse con la semblanza de gente cualquiera, más bien fea. [Palabras claves: esculturas olmecas, cabezas colosales, naturalismo, lo bello, lo feo.]

* Archéologue, directeur de recherche honoraire au CNRS [claude.baudez@orange.fr].

Journal de la Société des Américanistes, 2012, 98-2, pp. 7-31. (C) Société des Américanistes. 
« Drawings of captives from other cities emphasize the intention to degrade these unfortunates, and by contrast to emphasize the beauty and splendor of the victors. » (Spinden 1916, p. 444)

\section{INTRODUCTION}

Since our Western art tradition has put such a prize on naturalism, we tend to think that other civilizations valued it as much as we did and do. Naturalism or realism is often seen as the top end of the evolution of any art; as a consequence, it is also assumed that conventional, conceptual, stylized or abstract art came first, before developing into realism. When naturalism and conventionalism coexist, it is then expected that the most important subjects will be given naturalistic treatment, while the lesser ones will be expressed through conventions. The purpose of this paper is to show that this is not always the case, especially in the pre-Columbian civilizations of Mesoamerica, such as the Olmec and the Maya.

Olmec civilization ${ }^{1}$ blossomed in Mesoamerica starting with the beginning of the first millennium to the last centuries before our era. It was innovative in many areas, playing an important part in the elaboration of Mesoamerican calendar and arithmetic, and maybe in the invention of writing. The Olmecs developed monumental architecture and urban planning, and performed collective works that could have been produced only by strongly stratified societies. They had a very specific, easy-to-recognize artistic style, well illustrated in monumental stone sculpture, small portable jade sculpture, and ceramic vessels and figurines. The geographical distribution of small objects allows one to evaluate the expansion of the Olmec style, from Costa Rica to Michoacan, while most monumental sculptures are limited to the Gulf of Mexico area in politico-ceremonial sites such as La Venta, San Lorenzo, Laguna de los Cerros or Tres Zapotes.

Monumental in-the-round sculpture includes animals and humans, and many hybrids that are known as were-jaguars in the specialized literature. Also depicted in small objects, they are anthropomorphic creatures with emphasized feline features (Figure 8c). Some scholars (for instance Cyphers 2004) interpret these images as transformation figures, that is men - supposedly shamans transforming themselves into jaguars, an early case of what will be later called tonalism. Is it a dynamic image of transformation or a static representation of the combination of human and feline essences? Combinations of different beings are extremely common in "primitive » art without any indication of a possible « transformation ». To come back to were-jaguars, I have shown elsewhere that they are images of lightning, the force that brings rain and fertility but also strikes enemies and, as such, is an emblem of power in the hands of rulers (Baudez 2005). Of colossal size are the sculptures first interpreted as altars, then as thrones, and 
that are probably neither. They are huge rectangular pieces with a scene of emergence carved in high relief on one broad side. These emergence monuments are of two kinds; on one, the person emerging from a niche representing the maw of the earth monster (with feline attributes) holds on his lap a were-jaguar baby, while dignitaries are depicted in low-relief on the sides of the sculpture. On the other kind of emergence monument, the emerging personage holds ropes that restrain captives depicted on the sides.

\section{Colossal heads}

The colossal human heads make up another category. They measure from 1,47 to $3,40 \mathrm{~m}$ in height, and weigh from 6 to 50 tons. At least seventeen heads are known for the time being: ten from San Lorenzo, four from La Venta, two from Tres Zapotes and one from Rancho La Cobata. At San Lorenzo, Coe and Diehl (1980) have the heads dated from 1200 to $900 \mathrm{BC}$, preceding the supposed destruction of the ceremonial center; this dating however is not accepted by other scholars who criticize the stratigraphic placement of the monuments (see Hammond 1988; reply by Coe and Diehl 1991; rejoinder by Graham 1991); the critics also find puzzling « that [...] Olmec sculptures [were] violently destroyed and buried at San Lorenzo by 900 BC, Olmec sculpture in closely neighboring sites continued to be produced for many centuries to come... » (Graham 1989, p. 242).

Basalt is the material most frequently used (together with andesite, sandstone and schist), not only for the heads but also for other Olmec monumental sculpture. Its closest source lies in the Tuxtla mountains, not so far from Tres Zapotes, but at some $60 \mathrm{~km}$ and $100 \mathrm{~km}$ as the crow flies, from San Lorenzo and La Venta, respectively. In the absence of any draught animals, the transportation of these blocks, on rafts in waterways and dragged over logs on earth, required considerable and well coordinated human efforts.

At San Lorenzo, the heads were found in the central part of the site, forming two lines oriented north-south. At La Venta, Stirling discovered three heads at the extreme north of the ceremonial center (Mon. 2, 3 and 4). They formed a line oriented east-west (Figure 1a), and faced north, that is away from the area of monumental architecture. At the opposite end of the site (south), on Str. D-7, three very eroded sandstone figures $-2,60 \mathrm{~m}$ to $3,80 \mathrm{~m}$ high - were found together (Mon. 52, 53, 54. Figure 1b). They are squatting and seem to support a very important helmet with both hands. González Lauck (2004) observes that both groups of figures share a comparable helmet and are located at both extremes of the site's center. On the other hand, the stelae and altars are concentrated south of the main pyramid, not far from the center. 

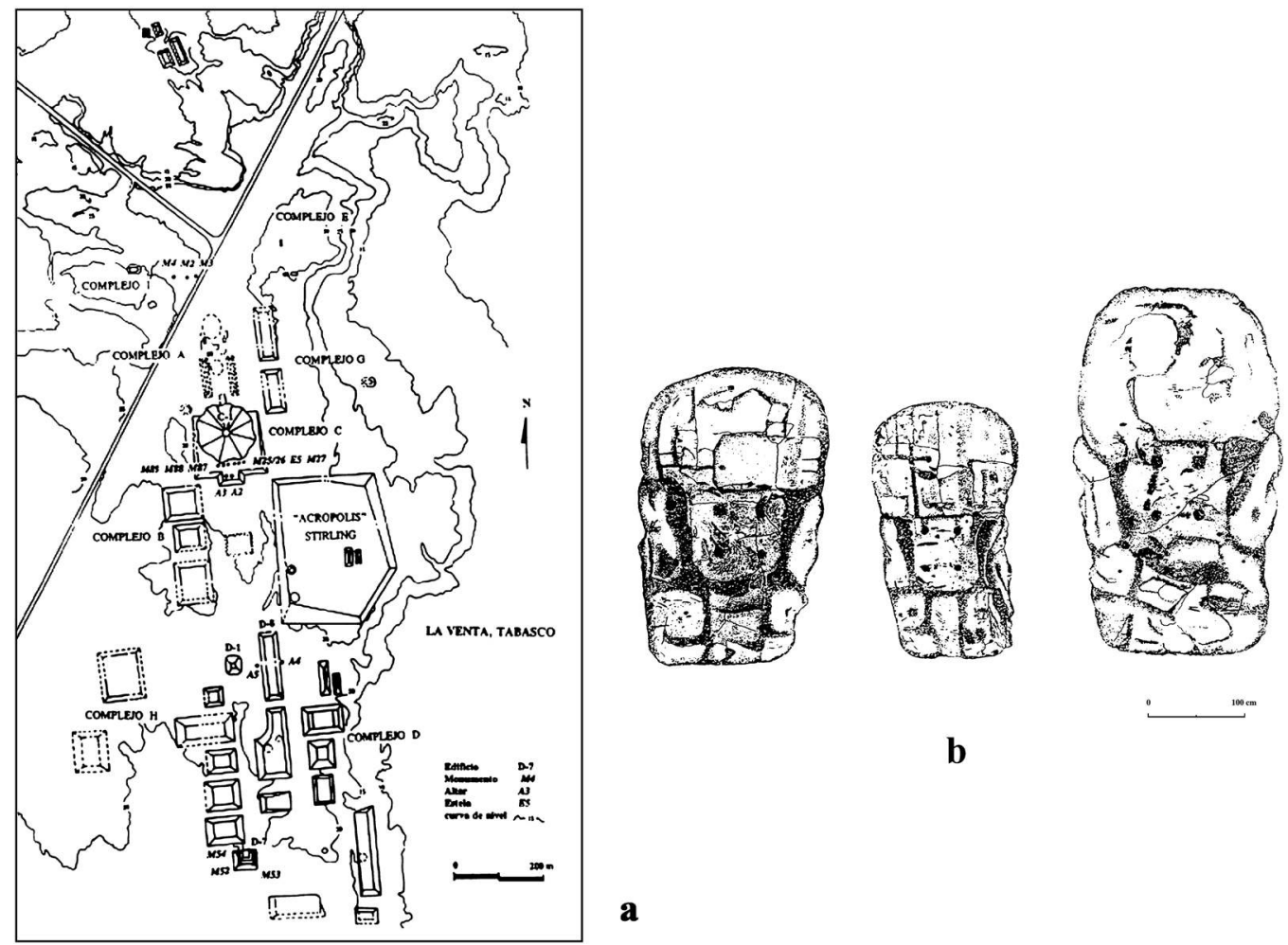

b

FIG. 1 - a. Map of La Venta; b. La Venta, Mon. 54, 52, 53 (after González Lauck 2004).

With only two or three exceptions, the heads have a flat, and mostly plain, back that originally was, according to Porter (1989), the top of the monuments traditionally called altars or thrones. According to this hypothesis, the great majority of the colossal heads had been carved out of them. Some heads - like San Lorenzo Mon. 2 and 53 - are even showing cracks on one side, that some scholars interpret as remnants of the altar's niche. Basalt being in the Gulf area a rare and expensive material, it may have occurred in a few instances that an obsolete monument was turned into a sculpture of a different type. Much harder to believe and justify would be the custom - spread on a vast territory and many centuries - of transforming all the so-called altars into heads. Besides, it may be observed on San Lorenzo Mon. 3 (Figure 2a) that the head's flatness occurred after the head was carved (one can still see faint traces of the ropes circling the head) and not before. 


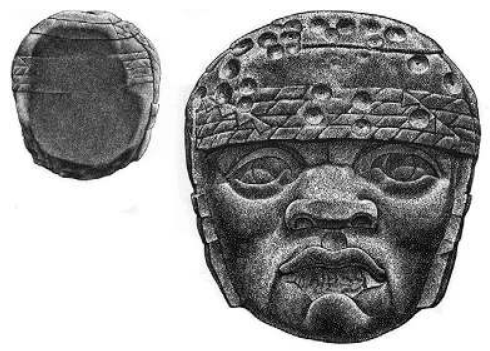

a
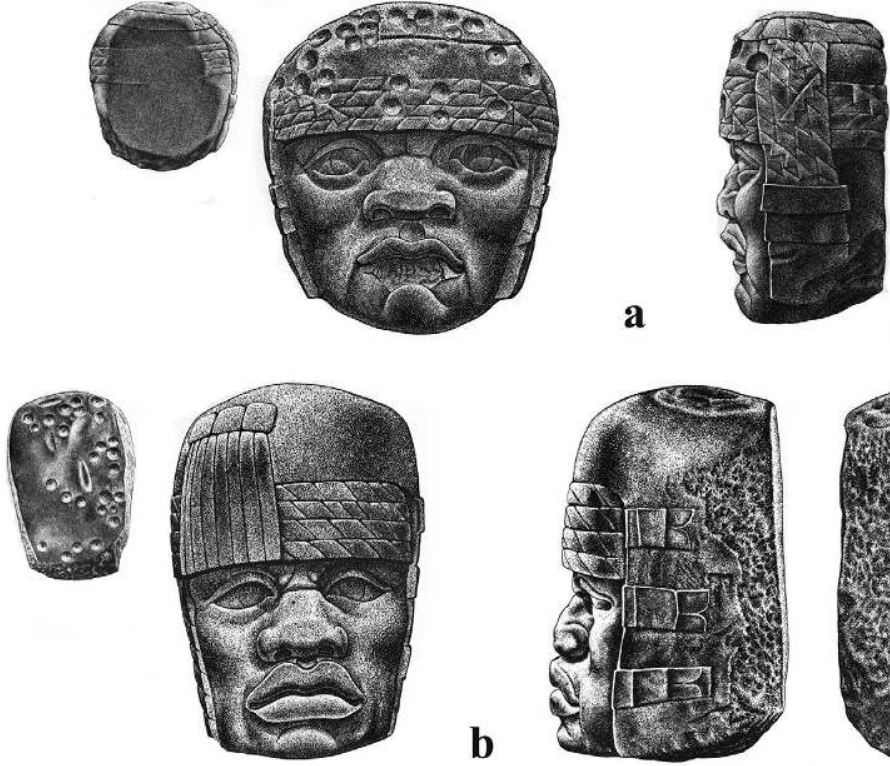

b
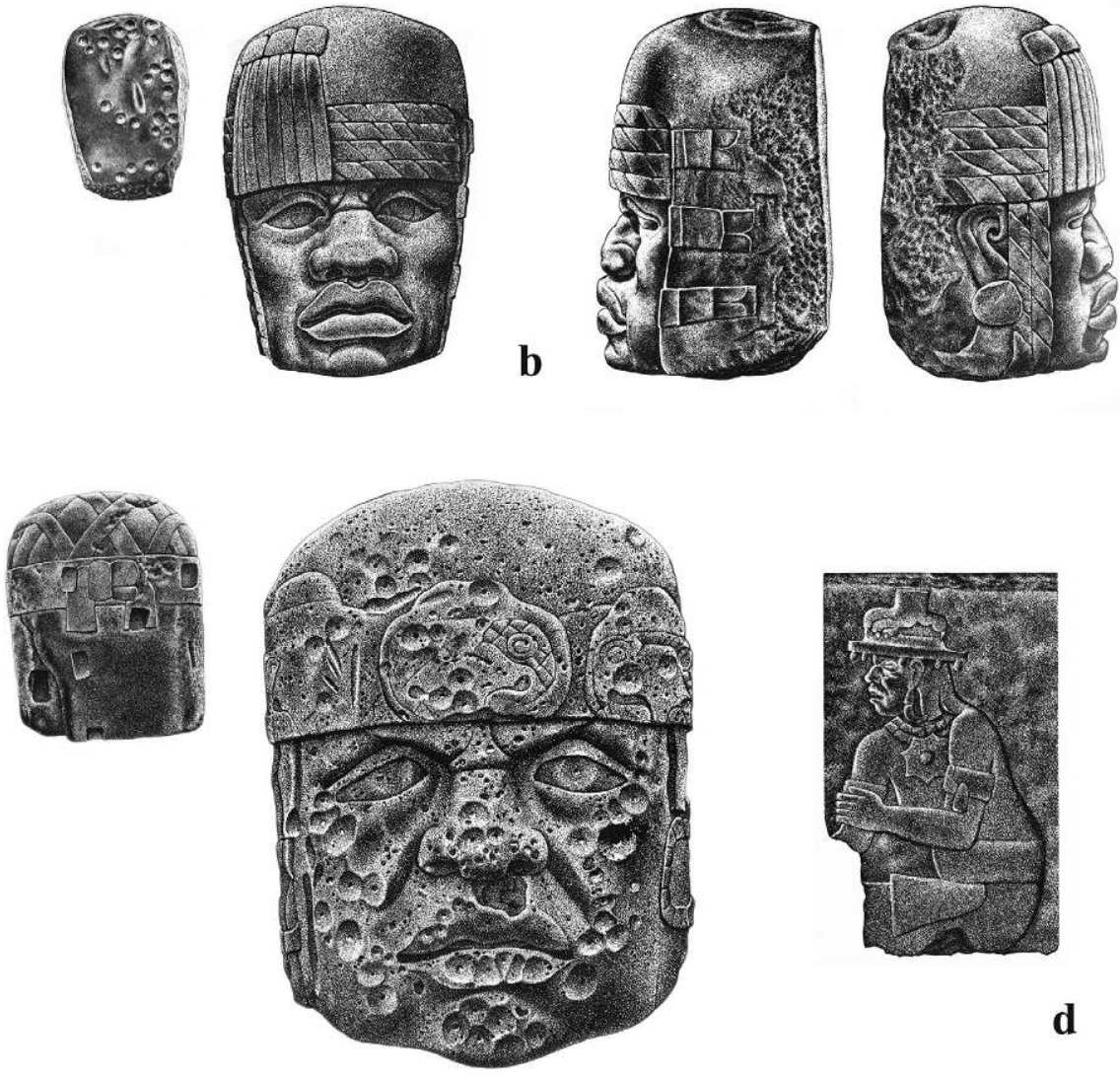

d

c

FIG. 2 - Monuments from San Lorenzo: a. Mon. 3: back, front, and left side. Ht: 1,78 m (after Coe and Diehl 1980, fig. 426); b. Mon. 4: back, front and sides. Ht: 1,78 m (after ibid., fig. 427); c. Mon. 2: back, front. Ht: 2,69 m (after ibid., fig. 425); d. Mon. 14: relief figure on right end. Ht: 1,83 m (after ibid., fig. 438). 
A simple alternative to Porter's theory is to suggest that the back of the heads is flat and plain because it was not intended to be seen, as if the heads were standing in rows (suggested in San Lorenzo as well as at La Venta), against a wall or an earth embankment ${ }^{2}$.

Although no two of the seventeen heads are identical, all of them have much in common. They are spheroid with a flat back, either left plain or carved only at the top. The hemispherical helmet takes up a third of the total height, and stops just above eyes' level. A chinstrap is in part visible on the heads' sides. The headgear often carries insignia on its front, such as parrot heads on San Lorenzo head 2 (Figure 2c), two paws or talons on San Lorenzo head 5. The narrow space between the eyes is anvil-shaped; the eyes, framed by two heavy eyelids, are large, almond-shaped and drooping; they are wide open, except on the head from La Cobata (Figure 3b), where they are closed. Round pupils are indicated as relieves or hollows and, to some scholars, the heads are squinting. The nose is broad even at its base and, at the end, it is flattened with two nostrils indicated by round depressions. Deep seams flank the nose. Cheeks and chin are slightly prominent. The lips are thick, sometimes parted, showing teeth. Two heads (San Lorenzo 9 and La Venta Mon. 2, Figure 3c) are smiling.
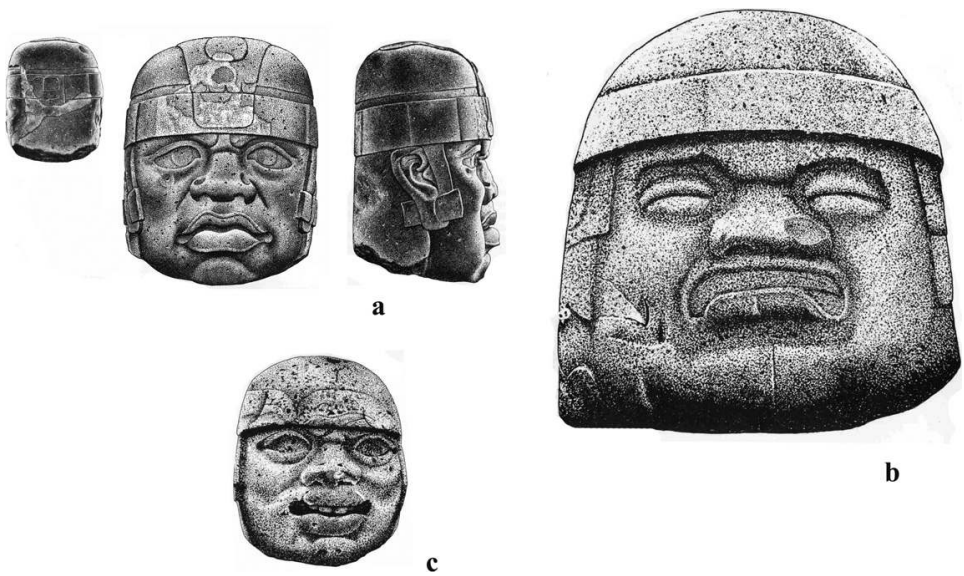

b

FIG. 3 - Three Olmec colossal heads: a. San Lorenzo, Mon. 1, back, front and right side. Ht: 2,85 m (after Coe and Diehl 1980, fig. 423); b. La Cobata, Mon. 1. Ht: 3,40 m (after Arqueología Mexicana suplemento, 12, 1995); c. La Venta, Mon. 2. Ht: 1,63 m (after Arqueología Mexicana suplemento, 12, 1995).

\section{Were they portraits of individual rulers?}

Most specialists interpret the heads as « portraits of individual rulers » (Coe and Diehl 1980, p. 293). La Fuente (1995, p. 25) writes that « but for the La Cobata head - that represents a dead individual -, the other sixteen are faithful 
enough portraits of Olmec (living) rulers and sacred individuals ». In the same issue of Arqueología Mexicana, Grove (1995, p. 32) states that they are « faithful enough portraits of Olmec rulers who can be identified for the personal attributes shown on the large insignia displayed on the helmets of every head ». I wonder how Grove can determine as personal and not social, the attributes shown on the insignia. Cyphers (from the same source 1995, p. 45) writes that « most specialists agree that the heads represent important people; they however disagree on their function as warriors, ball players and/or rulers ». Pasztory (2000) begins her paper "The portrait and the mask: invention and translation » with: "The Olmec portrait heads astonish Westerners... », a sentence not open to discussion. With the only exception of Cyphers, who hardly half-opens the door to doubt, the general belief is that the heads are portraits of rulers. The implicit syllogism goes as follows: the heads are realistic, and since portraits are realistic, therefore the heads are portraits. If they are actually portraits, it is assumed that rulers were the most probable models.

Portraiture in Mesoamerican art has not received the attention it deserves from either art historians or archaeologists ${ }^{3}$. In the rare occasions when the subject is dealt with, portraiture is mistaken for naturalism and is not demonstrated but perceived as obvious. Unlike Spinden (1916, p. 446) who « at neither Copan nor Quirigua [was]... able to find certain proof of portraiture », Kubler (1969) was one of the first scholars to "discover » it among Maya rulers at Quirigua. On stelæ dedicated to the same ruler, he compares the features of the king from age 27 to age 52 on a series of several dated monuments. He notices that the "sculptor distinguished rounder juvenile head and body forms from mature elongation and articulation ». I would say that the same can be observed on Copan Stela $\mathrm{C}$, a monument where a young ruler with a round juvenile face very similar to the face on Quirigua Stela J, succeeds his father depicted with an elongated face and beard. The Kubler's statement that the artist " was able to characterize individual traits » is much less convincing. When Kubler (ibid., p. 15) writes that « a portray identity between the two representations is evident » what is evident to me is that the same carvers or carvers from the same generation and from the same workshop produced the same canonic depictions of their ruler.

Schele and Miller (1986) commenting on Palenque sculpture state that « the portraits from Palenque are the most lifelike [my emphasis] especially the threedimensional heads modeled in plaster for use as architectural sculpture ». When the authors write that « one of two portraits of Chan-Bahlum found in the rubble of Temple 14 in Palenque is complete », one may wonder how they knew that the " portrait » was in fact Chan-Bahlum's? Was it written on it? Later they refer to " a handsome plaster head of a man... remarkable for the intensity of emotion [my emphasis] expressed in the face » (ibid., pp. 64-65). Once again, they mistake naturalism for portraiture, since a face may express emotion without being an individual portrait ${ }^{4}$. Pasztory $(2005$, p. 63) shares the view of the authors quoted 
above, when she writes: « ...archaeologically only images with a high degree of verisimilitude [my emphasis] are considered portraits ». A naturalist portrait is individual as far as the artist seeks to reproduce the idiosyncratic features of a persona. The reproduction of these features allows the viewer to recognize instantly Nero, Augustus or Stalin. Generally, these idiosyncrasies are irregularities or defects in shapes or proportions of individual features. Naturalistic portraits differ from psychological and imaginary portraits such as those of Homer and Socrates by Lysippe, or Pericles by Cresilas (Charbonneaux 1969, p. 172), in which psychological traits are translated into physical features. The idealized faces of Classical Greek sculpture are realistic and perfectly human but are not portraits in the sense that they do not refer to individuals, even if models were used by the artists who made them. These idealizations suited warriors and athletes as well as gods.

The wide-open eyes of the Olmec colossal heads (with only one exception, Figure $3 b$ ) accentuate their naturalism and their « lifelike» aspect. Since the La Cobata head is said to represent a dead person, the other heads are implicitly « alive ». This is misleading since severed heads are often shown open-eyed. Some Danzantes do not seem to have closed eyes and the heads held by the seated ceramic figures from Monte Alban IV Burials 58 and 103, are open-eyed. The trophy heads from Costa Rica and Panama also have open eyes.

In short, portraiture must not be mistaken with naturalism. Lifelikeness, verisimilitude, or emotional expressions are not criteria for portraits. The latter must not be assumed; they have to be demonstrated through the recurrence of individual features. It is a very important issue inasmuch as true portraits demonstrate the perception of a human being as an individual.

Among the specialists who have dealt with the Olmec colossal heads, the royal nature of the latter is also assumed and not argued. There is no doubt that the colossal size of these monuments, the amount of hardship involved in their transport seem to be only suitable to rulers. I think the heads were indeed ordered by rulers for their greatest glory, not to represent themselves but their enemies, defeated and sacrificed thereafter. In Mesoamerica, more importance is oftentimes given to captives or victims, than to their victors. The «Danzantes » of the Post-Olmec Monte Alban I (500-150 BC) is a case in point (Scott 1978). Some 300 slabs were brought over, dressed, carved with a generally naked and emasculated sacrificial victim, then set on the terraces of pyramidal structure L. While no corresponding victorious figure was found with them, slabs showing severed heads were displayed in the same context, and a few colossal heads are known from the area (ibid., pp. 12-13, fig. 3-4).

In the following period (Late Preclassic), the same pattern can be seen on structure A at Dainzú, Oaxaca (Baudez 2011-2012). This building was graced with dozens of slabs depicting falling ritual fighters presented as losers and future victims. Their victors were illustrated only twice on the structure A slabs and once on a rock on the top of Cerro Dainzú (Orr 1997, fig. 2.8). The fourteen slabs erected 
against a Classic structure at Nopala (Urcid Serrano 1993, fig. 16) represent twelve human figures with submissive gestures and only two victors holding knives.

The most famous example comes from the East Court of the Palace at the Classic Maya site of Palenque. Nine slabs representing submissive figures carved in a very crude style were set along the basement wall on both sides of the stairway leading to structure A (Figure 10a, b). Several authors (such as Greene Robertson 1985 , p. 62) have compared the limestone slabs, some 2,50 m high, with the Danzantes sculptures.

\section{Or severed heads?}

I argue that the Olmec colossal heads are not portraits of rulers, but represent the severed heads of sacrificed victims ${ }^{5}$.

The tradition of human sacrifice by decapitation has a long history in Mesoamerica, and images of headless victims or trophy heads occur everywhere in Pre-Columbian America. It is then very unlikely that the Olmecs would be the only people in Mesoamerica to have refrained from decapitating their victims and if they were indeed head-cutters, it is hard to imagine them representing their rulers in head form, looking exactly like the adversaries they were sacrificing.

We discover in the headdresses and ears of some Olmec colossal heads symbols of captivity and sacrifice that were displayed later by the Maya of the Classic period. Several turns of rope cover or make up the headband of San Lorenzo Mon. 3 and 4 (Figure 2a, b) like those worn by many Maya captives. Monument 3 has, besides, serrated bands or ribbons in several places of the headdress (Figure 2a), which recall the serrated ribbons passing through the ear lobes of the captives on the Palenque Tablet of the Slaves (Figure 9a). The left side of San Lorenzo Mon. 4 shows three superimposed bow ties with forked ends (Figure 2b; Coe and Diehl 1980, fig. 427), a common symbol of sacrifice among the Maya and other cultures of Mesoamerica.

The ear ornaments of some heads (San Lorenzo Mon. 1, 6, 9; Tres Zapotes Mon. A and Q, La Cobata Mon. 1) have been wrongly interpreted as tubes (Figure 3a); these rectangular elements are both thin and flat and look rather like the paper ribbons that Maya captives wore (Figure 9b). The ornaments worn on the ears by three other heads (San Lorenzo Mon. 4 and 5, La Venta Mon. 2) are composed of a disk and a curved element (Figure 2b); the same item can be seen at the ear of the captive carved in low-relief on the right side of the San Lorenzo Mon. 14, an emergence monument (Figure 2d). A rope held by the emerging figure from the monument's niche restrains the captive, who is wearing armbands and may be doing a submissive gesture.

The colossal heads wear a hemispherical helmet that appears as a protective device, with chinstrap and without projecting top or side elements such as those that come with other headdresses. The helmet includes a crown, often composed of bands forming a net, and a headband that strongly fixes it. 
Assuming the helmet had a protective function, for what kind of confrontation was it worn? I cannot think of more than three possible answers: war, ball game or ritual battle.

If we are to believe war imagery in sculpture (Yaxchilán), mural painting (Bonampak, Cacaxtla), painted vessels, figurines, and pictographic manuscripts, in Mesoamerica, the warrior's headdress was more emblematic than protective; it most often consisted of an animal helmet (figuring a feline, or a reptile, a deer, a bird, etc.) completed with feathers and other adornments. It is however very possible that these cumbersome headdresses were never worn in real combat, but only on the images that represented it, with the purpose of informing the viewer on the name, origin, or status of the warriors they depicted.

The same applies to the ball players who are shown with complex emblematic headdresses on reliefs from Yaxchilán, Copan or Chichen Itza; sometimes the players wear a simple headband (Tepantitla) or are even bareheaded (Codex Mendoza, Codex Magliabechiano). In any event, the chronicles, be they indigenous or Spanish, do not refer to any game in which the head was used to strike the ball.

Ritual battles are defined as agreed upon confrontations whose end was not to kill most of your opponents as in a conquest war, nor to capture future sacrificial victims as in a capture war. From Preclassic times, ritual battles were waged in Oaxaca (Dainzú), in the Maya area, in Pacific Coast Guatemala and in the central Mexican Highlands (Baudez 2011-2012). The purpose of the ritual battle « to death » was to produce sacrificial victims; the latter were either killed « accidentally » during the fight, or wounded, to be later sacrificed. Both parties belonged to the same community or to neighboring communities. Their weapons differed from those used in wars; they consisted in stones, either hurled at the other party or used as shock weapons (manoplas) in hand to hand combat. In order to avoid slaughter, the fighters protected themselves with thick garments and a helmet; the additional purpose of the latter, was to conceal the winners' identity. Sometimes, such as at Teotihuacan, it was a mask that insured their anonymity in order to avoid vendettas. The Teotihuacan and the Olmec helmets bear a close resemblance, one to the other.

\section{Teotihuacan helmeted ritual fighters}

Teotihuacan hand-made figurines from the Tzacualli phase (1-150 AD) wear a hemispherical helmet similar to the Olmec colossal heads' headdress (Figure 4a-c). The much-stylized affair consists of a band that circles the forehead, and another one running across that forms the helmet's crown. A chinstrap fixes the whole thing. The head is globular with three circular depressions that recall the openings for eyes and mouth on a flayed skin mask.

In the following phase, the figurines are molded and more details are added (Figure $4 \mathrm{~d}, \mathrm{e}$ ). The openings of a thin and supple mask, more intended to hide 
than to protect the face, let see the eyes and mouth of the bearer. A helmet with chinstrap tops the mask. There is no trace of a nose, showing that it is not a flayed face. Multiple protections are shown at arms, legs and belt level; something looking like a rolled up cloth, crosses the chest from the shoulder to the opposite hip. Some molded figurines wear behind the head, a frame adorned with rosettes.

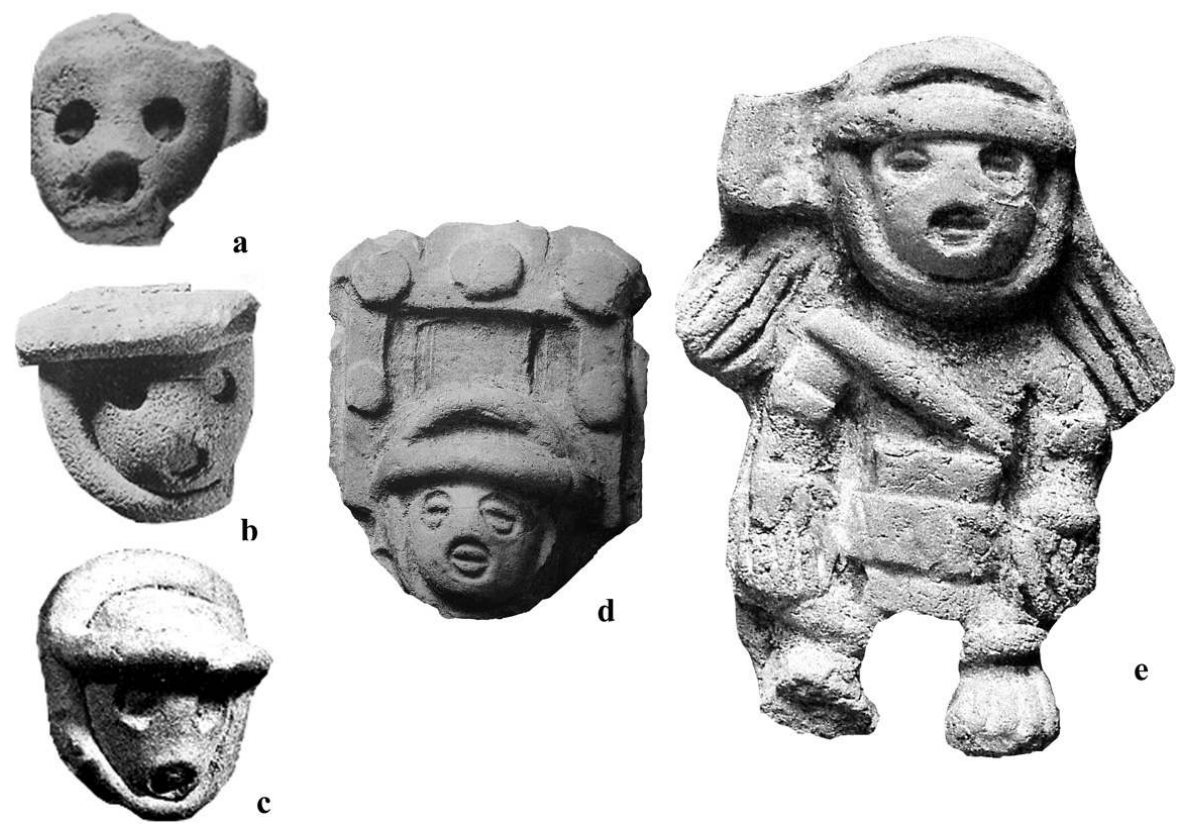

FIG. 4 - Teotihuacan: helmeted and masked figurines: a, b, c. Hand-made figurines; d, e. Molded figurines (after Scott 2001).

While Seler (1990-1998) first, then Gamio (1979), Armillas (1950), Caso (1966), Séjourné (1959) and others saw in these figurines images of Xipe Totec, von Winning (1987) was the first to question this interpretation. Scott (1993) saw in these globes protective devices; Taube (1988) and Orr (1997, p. 164) suggested the figurines represented ballplayers. Lately, Taube and Zender (2009) considered them as representing « boxers », that is participants in a ritual battle. Because of their protective costume, different but comparable to the Dainzú fighters (Baudez 2011-2012), these figurines may have indeed represented fighters in ritual combats. The issue of the confrontation was the decapitation of the losers, be they dead or wounded. At Teotihuacan, the same head with helmet and mask but without a body, therefore supposed to be severed, is sketched on stones, such as the one found in the rubble of the Pyramid of the Sun, or engraved on a stela found by Gamio near the northwest corner of the Feathered Serpent pyramid (Figure 5a, b). 


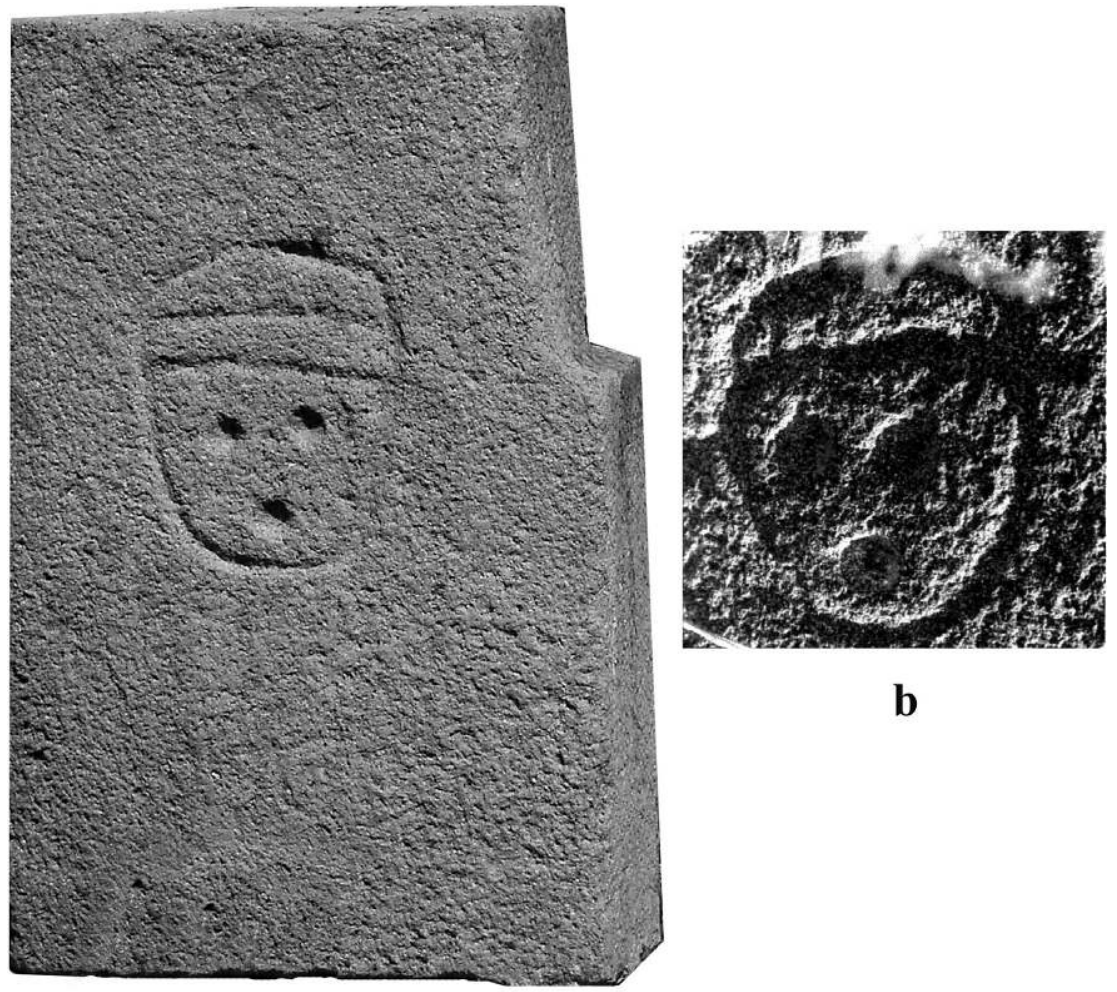

a

Fig. 5 - Teotihuacan severed helmeted heads: a. Carved slab. Ht: 0,90 m (after photo Baudez); b. Carved block (after photo Couvreur).

\section{Monte Alto colossal heads}

In the Pacific plain of Guatemala, the site of Monte Alto is well-known for its post-Olmec style of sculpture, dated by Parsons (1986, pp. 39-45) between 500 and $200 \mathrm{BC}$. It « includes relatively small pot-bellies, massive human-effigy boulder sculptures, and colossal boulder heads ». Pot-bellies and boulder effigies have been found elsewhere on the Guatemalan Pacific Coast, and also at Santa Cecilia, in El Salvador; in the Highlands, a dozen of potbellied sculptures have been reported from Kaminaljuyú. They represent bald individuals, naked with the possible exception of small earplugs and a collar; their puffy closed eyes are interpreted as those of dead persons. Five colossal heads from Monte Alto " mirror the facial features of the large effigy boulder sculptures » (ibid., p. 40) and are interpreted as severed trophies (Figure 6). Decapitation is illustrated at El 
Baul, not far from Monte Alto, with an intentionally decapitated potbelly sculpture with its arms crossed on the chest, a submissive gesture (ibid., fig. 112).
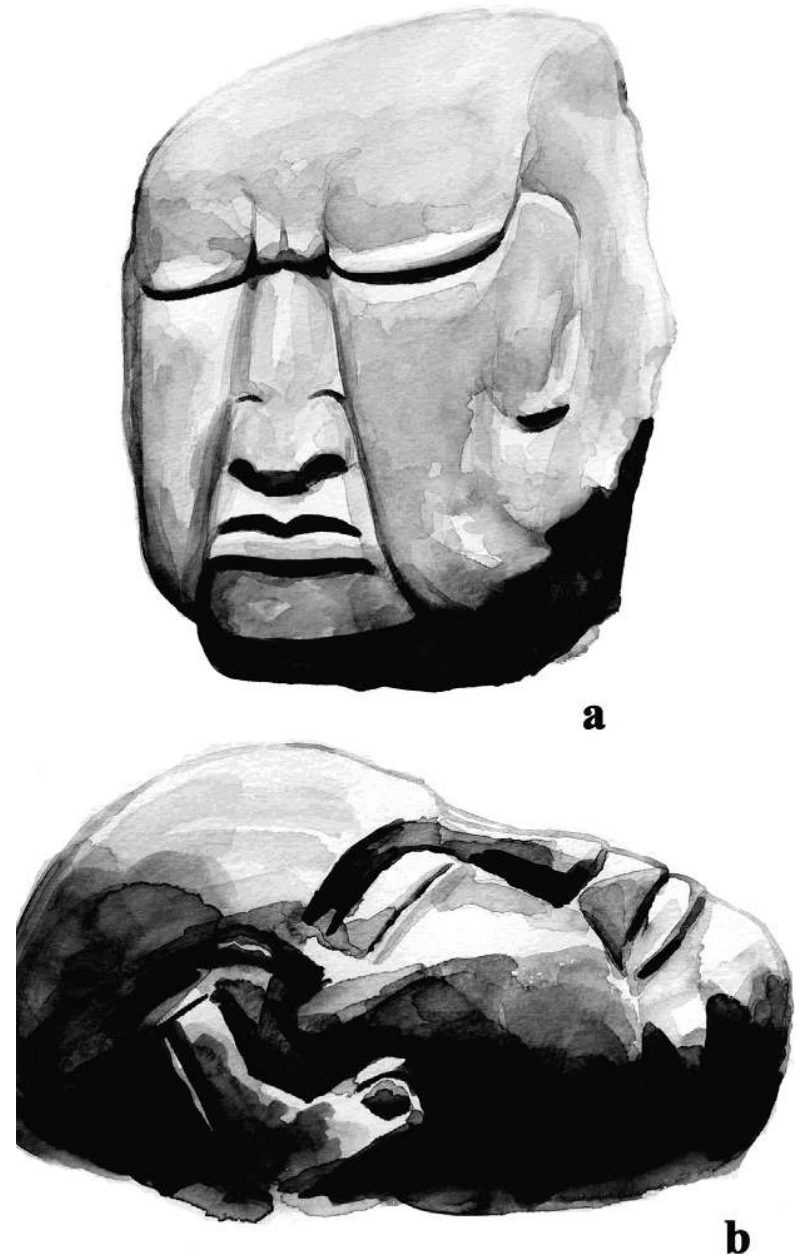

Fig. 6 - Colossal Heads from Monte Alto: a. Mon. 10. Ht: 1,45 m; b. Mon. 1. Ht: 1,27 m. Watercolors I. Bonzom (after Parsons 1986, fig. 123, 119).

At Monte Alto, the colossal heads (Mon. 1, 2, 7, 8, 10) are mixed with the other boulder sculptures. They form two groups: six of them are « lined up north to south on the extreme margin of the site »; the other four form an east-west row on the western limit of the settlement (ibid., p. 145, map 6). Like at La Venta, the sculptures that figured corpses and severed heads were placed on the margins of the site. 
Parsons (ibid., p. 45) views the heads « as the end of a long Preclassic tradition from the naturalistic helmeted, open-eyed, Olmec heads, to the bald, closed-eyed, relatively crude and stylized, boulder "trophy head" conceptions that ultimately were conceived on the south coast $"$. We may add that if we interpret the Monte Alto heads as severed trophies, there is every reason to consider likewise their Olmec forerunners.

\section{The Toniná colossal head}

Toniná is a Piedmont Maya site that shares many traits with the cultures of the Pacific Coast of Chiapas and Guatemala, such as the crossed-arms statues, the pegged sculptures and the effigies on pedestals. There we see the end of the colossal heads tradition with two monuments; Mon. 58 is a big - unfortunately very eroded - severed head, the other one Mon. 33 is the statue of a laying, naked, decapitated man (Figure 7).
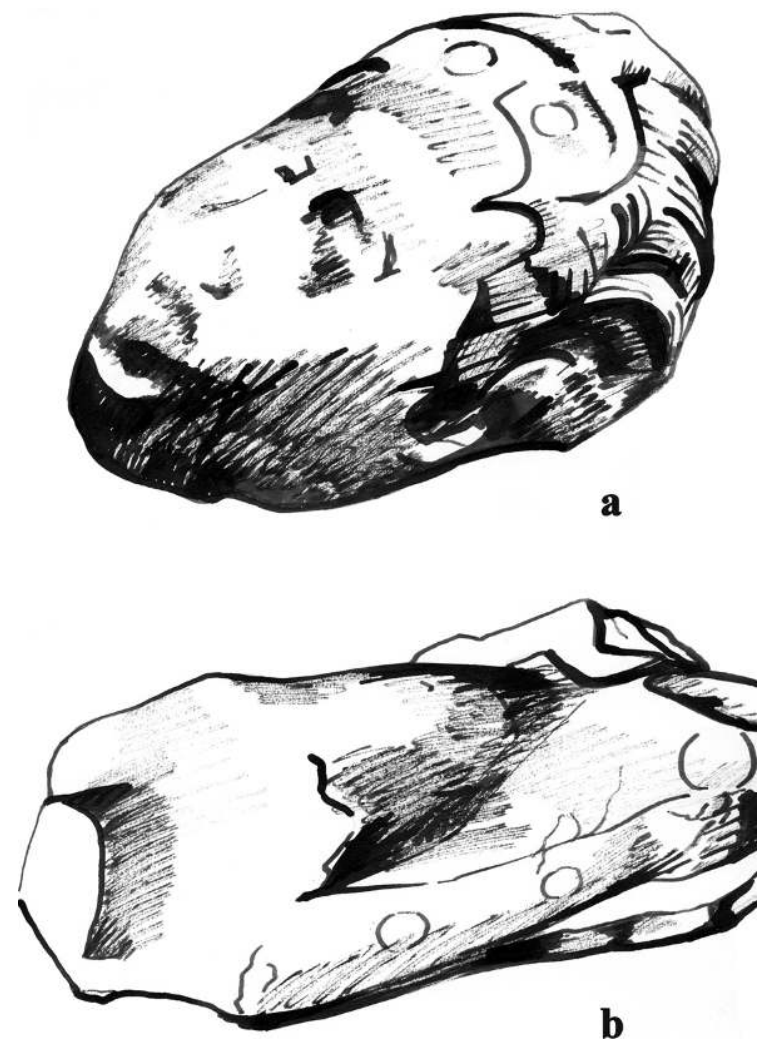

FIG. 7 - Monuments from Toniná: a. Mon. 58, Length: 0,80 m; b. Mon. 33, Length: 0,98 m (drawings I. Bonzom, after Becquelin and Baudez 1979-1982). 


\section{Perceptual and conceptual images}

Although disagreeing with Pasztory $(2000 ; 2005)$ when she shares the general opinion that the colossal heads are portraits of rulers, I think she is absolutely right when stating, " not all Olmec art is equally naturalistic ». She observes that in Olmec art coexist both the perceptual and the conceptual modes as defined by Gombrich (1960) ${ }^{6}$. The realism of the colossal heads contrasts with the conceptual approach used by the Olmec carvers when dealing with other sculptures. Pasztory states that since « conventionalized styles keep their viewers at an emotional distance », the portraits of rulers (i.e. the colossal heads) are made realistic " to create intimacy » and " eradicate the distance (of the rulers) with their subjects ». This conclusion is most surprising from Pasztory (2005) who in her last book claims that, in chiefdoms as well as in states, many " things » are created " to enhance the ruler's persona » and « to make status visible », that is to create « distance » between the ruler and his subjects. While agreeing with her that the realistic style of the heads " eradicate distance " with the viewers, I think that no distance, nor respect of any consideration is due to the heads if these are trophies of the enemy. On the other hand, the conceptual mode used when dealing with power figures creates the « distance » required between supernatural and political figures and their believers or subjects. I will go further by suggesting that in Olmec art the conceptual or conventional mode is positively biased, and was probably seen as « beautiful »; on the contrary, the perceptual or realistic was the negative, ugly mode.

\section{THE BEAUTIFUL AND THE UGLY}

The jaguars that belong to the group of sculptures at El Azuzul, near San Lorenzo, are seated with the front legs extended between the flexed hind legs (Figure 8a). The two human statues from the same group have a similar position: although seated tailor-fashion, their body is bent forward with the arms extended between the knees. The hands hold a tubular object. The same feline posture ${ }^{7}$ can be seen on a number of sculptures representing elite figures, for instance the « Príncipe» from Cruz del Milagro, Veracruz (Figure 8b), or Mon. 1 from San Martín Pajapán, or the sculpture from Cuauhtotolapán Viejo. It is as if these humans wanted to imitate the seated jaguar.

The other characteristic of the feline, frequently duplicated on humans, is his snarling mouth; it is arched with a thick turned up upper lip discovering a double row of threatening teeth. It is particularly developed on the creature called were-jaguar (Figure 8c), where gums and crossed fangs are usually shown. A major figure in monumental as well as in portable art, the were-jaguar is often held in the arms of rulers as a kind of scepter (Baudez 2005). Combining feline 
and human traits, it represents lightning and at the same time is an emblem of the earth. Its slanting eyes are wide apart and its head is divided into two by a split like the one that divides the forehead of the Maya earth monster. On human figures, the mouth, although less important, has also an arched upper lip, diagnostic feature of the feline mouth. The borrowing of feline posture and mouth by nobles and rulers means that they wished to appropriate qualities attributed to the jaguar and the were-jaguar. Sometimes, the same humans seek a feline look with eyes half-closed or slanted (Figure 8b, d). The eyes' outer corner never droops like those of the colossal heads. The nose is slightly flattened, and the whole face is inexpressive.

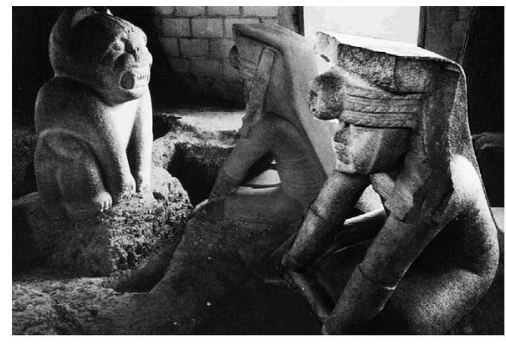

a

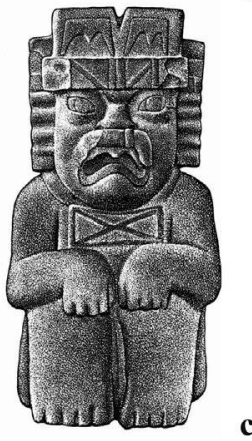

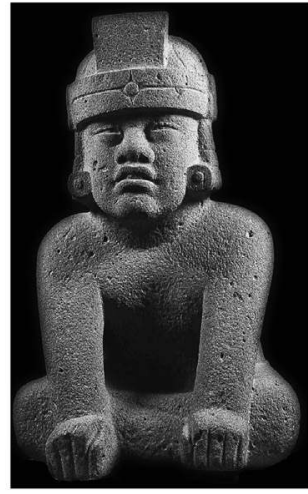

b

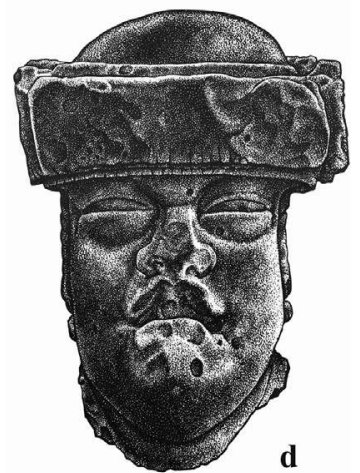

FIG. 8 - a. El Azuzul: seated jaguar and men (after Diehl and Coe 1995, fig. 8); b. Cruz del Milagro (Veracruz). Ht: 1,30 m (after Arqueología Mexicana, 12, 1995); c. San Lorenzo, Mon. 52, Ht: 0,90 m (after Coe and Diehl 1980, fig. 494); d. San Lorenzo, Mon. 6, Ht: 1,02 m (after Coe and Diehl 1980, fig. 429).

The features of the big heads contrast one to one to the traits of the other anthropomorphic sculptures (Figures 2,3). The colossal faces are broad and very rarely oval-shaped. Their large drooping eyes are narrowed, and it may be suggested that if they are shown open, it is to contrast them to the «feline look ». Their noses are very broad and flat. Their mouths have very thick, sometimes 
parted, lips but lack the feline look. Their chins protrude. Two colossal heads are smiling, a very improper expression for a political or religious figure, considering the general absence - the smiling figures from Veracruz being a notable exception - of this expression in Mesoamerican art. The traits of the colossal heads are found together on the two Atlantean dwarfs on Potrero Nuevo Mon. 2, an altar or throne (Coe and Diehl 1980, pp. 366-368, fig. 496). The figure on the left has a curved element on his hair that recalls those on the headband of San Lorenzo Colossal head 8 (or Mon. 61; see a drawing of the monument in the leaflet which accompanies Arqueología Mexicana, 12, 1995). The dwarf to the right has flat ribbons hanging from his ears. The two creatures were depicted as « ugly » (for the Olmec eye) for they probably represented captives or slaves in a subordinate position.

The first colossal head to be discovered was Tres Zapotes Mon. A in 1862 by Melgar. Commenting on this first encounter, Melgar (1869 quoted by Pasztory 2005) wrote: « what astonished me was the Ethiopic type represented. I reflected that there had undoubtedly been Negroes in this country ». Many publications and museum labels, up to the " 60 s, mentioned the Negroid features of the colossal heads. For Coe and Diehl (1980) who discuss the matter when describing San Lorenzo Mon. 1, its flat nose and other features are due to the original form of the boulder that the carver wanted to modify to a minimum to spare his effort ${ }^{8}$. Compared to the efforts spent to transport the stone from its source to the site, the carving of another nose to the figure appears to me as a mere trifle!

The fact that the colossal heads stand apart within the monumental sculpture receives support from the differential treatment they were subjected to, when the politico-ceremonial centers collapsed (Grove 1981). At San Lorenzo, only the head of Mon. 6, a huge in-the-round figure with an estimated height of 2,33 m, has been found, the body supposedly smashed into pieces (Figure 8d). Monuments 14, 20, the so-called table-top altars with scenes of emergence, have been severely mutilated. Seated human figures such as Monuments 11, 12, and 24 have been decapitated and hammered. Animal figures (Mon. 7, 9, 37) have also been decapitated. The only sculptures that have not been vandalized are the colossal heads, although Coe and Diehl (ibid., pp. 297-298) do not share this view. They think that the heads have been defaced by pitting (evidenced by both " dimpled pits » and " ground pits »). I personally think that both pits, because of their random distribution, are not the results of human action. Take the heavily pitted face (on which Coe and Diehl have counted sixty pits) of Mon. 2 (Figure 2c) and observe that the pits are evenly distributed all over the face and that no features, such as eyes or nose, are broken up or erased, like what would happen if one wanted to deface a portrait. On Mon. 1 (Figure 3a), " one dimpled pit occurs below the right eye, [and] two possible ground pits on both alæ of the nose » are not signs of intentional mutilation. The front of Mon. 4 (Figure 2b) is almost intact, while 26 dimpled pits were counted « on the flat surface at the rear 
of the head». Coe and Diehl (ibid., p. 306) then "wonder whether these pits might not represent constellations ». Are they also evidence of mutilation?

Assuming the big heads represent sacrificed "ugly» losers, it is understandable why they were spared the rage of iconoclasts who rather directed their blows toward the « beautiful » images of power, such as emergence scenes, rulers, mythical animals, and the like.

Some five centuries after La Venta, a similar situation existed in Oaxaca, according to the differential treatment of representations associated with power and religion on one hand, and images of sacrificed victims on the other. The anthropomorphic faces of Monte Alban I and II generally display the arched Olmec jaguar mouth, while the Danzantes have rounded heads, flat noses and thick lips ${ }^{9}$.

I think the Classic Maya also had beauty canons for the representations of their rulers and nobles and in contrast to these canons, had criteria for ugliness that they applied to the people they could despise, such as war captives or sacrificed victims. Since the foes of every Maya kingdom were generally fellow Mayas from another neighboring kingdom, there is no reason to think that they could be of a distinct physical type. It is not a situation comparable, for instance, to Nubians and Egyptians. Therefore the iconographic differences between Maya victors and vanquished were purely cultural. They were treated in opposite features: narrow/ broad, short/long, thin/thick, shaved/bearded or mustachioed, etc.

Many scholars consider the arch-famous stucco head found under the sarcophagus in the tomb of the temple of the Inscriptions at Palenque, as the epitome of Classic Maya beauty. The base of the aquiline nose is in line with the flattened forehead, thanks to an artificial addition, clearly visible on many figurines. The eyes are round and not too big, the cheeks are slightly protruding, the lips are thin with a tendency for unequal length. The face is hairless or carefully shaved ${ }^{10}$ and the chin slightly protruding.

It is true that many Maya faces - included those of captives - follow these same canons. Other sculptures however use the opposite features as a depreciative gesture, such as captives from Palenque and Toniná (Figure 9). Note the moustache, the big nose and the irregular profile of the forehead and nose.

Another way of presenting the ugliness of the enemy is illustrated by the big submissive figures carved on the slabs that cover the basement wall of House A in the East Court of the Palace at Palenque (Figure 10a, b). Here ugliness is not expressed through the face features that are genuinely Mayan, but through the lack of symmetry of the whole composition, and the non-respect of proportions within every particular figure and between the figures themselves (Robertson 1974; Greene Robertson 1985). All four captives to the left of the stairway face it, but the last figure of the row turns his head in the opposite direction; to the right of the stairway, only the first figure faces it, while the other four give their back to it. The proportions of the head to the body vary from one individual to the other, 


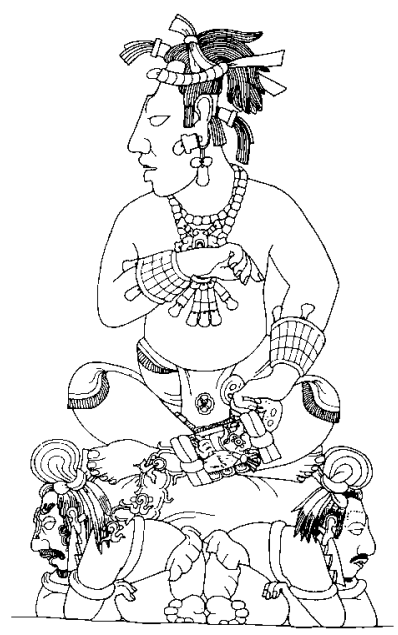

$\mathbf{a}$

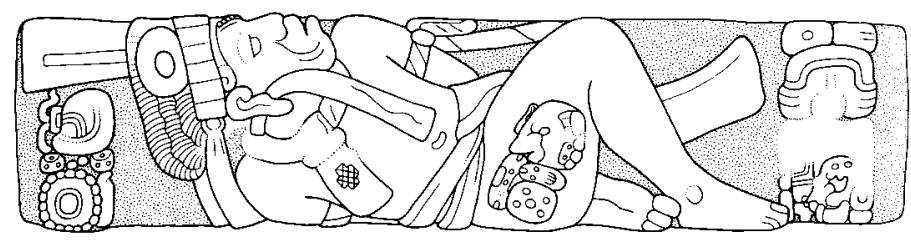

b

FIG. 9 - Maya captives: a. Palenque, Tablet of the Slaves, central icon (after drawing by Greene Robertson 1985); b. Toniná, Mon. 27 (after drawing by J. Graham).

and the respective size of the figures varies too. We are not able to decide whether the smaller captives are dwarfs because we do not even know whether some figures are standing or kneeling. As Robertson (1974, p. 105) noticed: « All of these figures without exception have been cut off at the tops of the individual slabs ». He also remarked that «there are differences among them in terms of pose, proportions, technical approach to the problems of the sculptor, and expressive power » (ibid.) and concludes that « they do not make up a systematic and collective unity ». In other words, he suggests that the slabs as a whole were not originally carved for the basement wall against which they now stand, and probably come from different buildings or places. Be that as it may, the stones have been assembled in the East Court with the likely purpose of impressing the viewer with both their size and their « ugliness ». Peter Mathews and I have even 
proposed that the captives themselves were forced to carve the slabs (Baudez and Mathews 1978). While this is very possible, it is not demonstrable. What matters here is that the Mayas took great pains to move, modify and set these very crude slabs against a structure that was graced by stucco relieves that fully respected the Maya beauty canons. The same opposition is evidenced near the top of the pyramid of the Inscriptions, where two slabs of the same style representing kneeling captives frame the last steps of the stairway that lead to the temple platform; they drastically contrast with the refined stucco reliefs that grace the temple a few meters away.

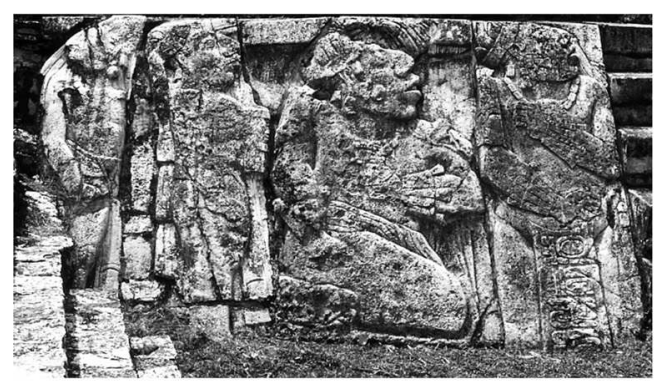

a

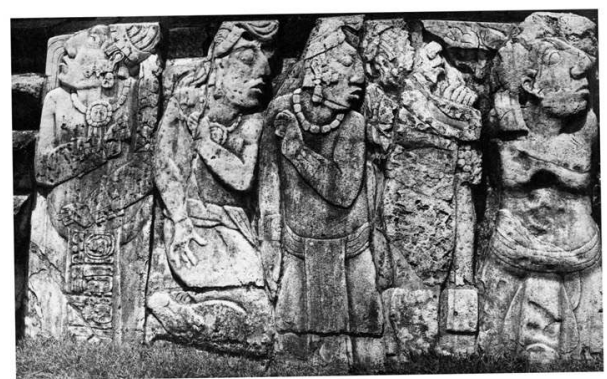

b

FIG. 10 - Palenque, submissive figures: Palace, East Court, on both sides of stairway leading to Str.A (photos Baudez).

The Maya carvers, like their Olmec colleagues, had their art severely constrained when they were dealing with representations of their rulers and supernatural beings. They had to conform to many conventions concerning the posture, the anatomy, the costume, the political and religious paraphernalia. These constraints did not exist with captives and victims, the artists being limited only by technical and space considerations. In this domain, naturalism was taking over the conceptual approach, as demonstrated by the Tonina captives much more « realistic », in low as well as high relief, than their victors. 
The Greeks, from the archaic period into the Classical age, had developed beauty canons to build up the ideal picture of the Greek man confronting the barbarian world ${ }^{11}$. For the Olmecs and other Mesoamerican peoples, beauty was also used to construct their identity. The ugliness of the others highlighted to their own beauty. *

* Manuscrit reçu en janvier 2012, accepté pour publication en mai 2012.

\section{NoTES}

I would like to thank Rebecca González and John Graham for their helpful comments on a first version of this paper.

1. When using the expression "Olmec civilization », the word Olmec defines not only an art style, but the cultural (religious, political, social, etc.) context out of which this style developed.

2. Graham reminds me that this idea was first suggested by Stirling $(1965$, p. 734$)$.

3. Nevertheless, recently Filloy (2011) has raised and discussed at length the problem of the existence of portraits in case of the most famous Palenque king.

4. See for instance the « character heads » sculpted by Frank Xaver Messerschmidt (1736-1783).

5. Graham again brought to my attention the following quotation: " ¿Serán tal vez también las cabezas monumentales de La Venta reminiscencias de un culto a la decapitación? »(Knauth 1961, p. 197). No arguments were then presented to back up this first suggestion that the colossal heads may have represented severed heads.

6. Conceptual art is when people represent what they imagine; perceptual art or naturalism is when people match the image in their minds to reality. According to Robertson (1974), these concepts had been already defined and used by Loewy (1907).

7. See also San Lorenzo Mon. 37 (Coe and Diehl 1980, fig. 471).

8. "To sculpt this face with an "Indian on the Buffalo nickel" nose would have meant removing several additional tons of basalt by the most tedious process and would have increased the chances of breakage in transport, if the monument had been carved near the source- thus it was easier and more efficient to produce portraits in this "Negroid" style " (Coe and Diehl 1980, p. 300).

9. «[... most Danzantes do have extremely thick lips which protrude to meet the tip of the nose. These lips, with the thick fleshy nose, give the Danzantes a negroid cast which recall certain Olmec figures. The colossal heads come to mind, although they probably could not have been seen by the Oaxacan carvers » (Scott 1978, p. 18).

10. Some Maya rulers may wear, as an age marker, a beard, real or false like on some Quirigua stelae (Kubler 1969) or on the deceased king on the west face of Stela $C$ whose features contrasts with the young traits of Eighteen Rabbit pictured on the east face of the same monument.

11. "Le refus du portrait vrai par le classique pur répond aux exigences profondes de l'hellénisme, qui s'exprimaient déjà, dès l'époque archaïque, par la création du couros nu, image idéale de l'homme grec face au monde barbare. L'intellectualisme classique met au point une mesure humaine qui tend à l'universel » (Charbonneaux 1969, p. 172).

\section{REFERENCES CITED}

\section{Arqueología Mexicana}

1995 «Los olmecas, mapa del mundo olmeca », Catálogo Cabezas Colosales, Suplemento de la revista, II (12), marzo-abril. 
Armillas Pedro

1950 «Teotihuacan, Tula, y los Toltecas: las culturas post-arcaicas y pre-aztecas del centro de México. Excavaciones y estudios, 1922-1950 », Runa, 3 (1-2), pp. 37-50.

BAUDEZ Claude-François

2005 «Le bébé-jaguar olmèque, une créature mythologique emblématique du pouvoir », Religions \& Histoire, 1, pp. 86-93, Dijon.

2011-2012 «Las batallas rituales en Mesoamérica », Arqueología Mexicana, 112, part. I, pp. 20-29; 113, part. II, pp. 18-29.

Baudez Claude-François and Peter Mathews

1978 "Capture and sacrifice at Palenque », in Merle Greene Robertson and Donnan Call Jeffers (eds), Tercera Mesa Redonda de Palenque, IV, PreColumbian Art Research Center, Monterey, pp. 31-40.

BECQuelin Pierre and Claude F. BAudez

1979-1982 Tonina, une cité maya du Chiapas, 3 vols, Mission archéologique et ethnologique française au Mexique, coll. «Études mésoaméricaines », Éditions Recherche sur les civilisations, Paris/Mexico.

CAso Alfonso

1966 «Dioses y signos teotihuacanos », in XI Mesa Redonda, 1, Sociedad Mexicana de Antropología, Mexico, pp. 249-279.

CoE Michael D. and Richard A. DielH

1980 In the land of the Olmec. Vol. 1. The Archaeology of San Lorenzo Tenochtitlán, University of Texas, Austin.

1991 "Reply to Hammond's "Cultura hermana: Reappraising the Olmec" ", Quarterly Review of Archaeology, 12 (1), pp. 30-35.

Charbonneaux Jean

1969 «Sculpture», in Jean Charbonneaux, Roland Martin et François Villard, Grèce classique, Éditions Gallimard, coll. «L'Univers des Formes », Paris.

CYPHERs Anne

1995 «Las cabezas colosales », Arqueología Mexicana, II (12), pp. 43-47.

2004 Escultura olmeca de San Lorenzo Tenochtitlán, UNAM, Mexico.

DielH Richard A. and Michael D. CoE

1995 "Olmec archaeology », in The Olmec world. Ritual and rulership, The Art Museum/Princeton University, Princeton, pp. 11-25.

Drucker Philip, Robert F. HeIzer and Robert J. SQUIER

1959 Excavations at La Venta, Tabasco, 1955, Smithsonian Institution, Bureau of American Ethnology, Bulletin 170, Washington.

Filloy Laura N.

2011 Costume et insigne d'un roimaya de Palenque, K'inich Janaab Pakal. Vie et mort d'un souverain maya du Classique récent, $\mathrm{PhD}$, Université de Paris 1, Paris.

Gamio Manuel

1979 La población del valle de Teotihuacan, 3 vol., Dirección de Antropología, Secretaría de Agricultura y Fomento, Mexico [1922]. 


\section{GOMBRICH Ernst}

1960 Art and illusion, Princeton University Press, Princeton.

GonZaLez LaucK Rebecca

2004 «Observaciones en torno a los contextos de la escultura olmeca en La Venta, Tabasco », in Ma. Teresa Uriarte and Leticia Staines Cicero (eds), Acercarse y mirar. Homenaje a Beatriz de la Fuente, UNAM, Mexico, pp. 75-106.

GRAHAM John

1989 «Olmec diffusion: a sculptural view from Pacific Guatemala », in Robert J. Sharer and David C. Grove (eds), Regional perspectives on the Olmec, Cambridge University Press, coll. « A School of American Research Book », Cambridge, pp. 227-246.

1991 «Through the looking glass: a rejoinder to Coe and Diehl's "Reply to Hammond" ", Quarterly Review of Archaeology, 12 (3), pp. 39-45.

GreENe Robertson Merle

1985 The Sculpture of Palenque. Vol. III. The late buildings of the Palace, Princeton University Press, Princeton.

Grove David C.

1981 "Olmec monuments: mutilation as a clue to meaning », in Elizabeth Benson (ed.), The Olmec and their neighbors. Essays in memory of Matthew W. Stirling, Dumbarton Oaks, Washington, pp. 49-68.

1995 «Los Olmecas », Arqueología Mexicana, II (12), pp. 26-33.

HAMMOND Norman

1988 «Cultura hermana: reappraising the Olmec », Quarterly Review of Archaeo$\log y, 9$ (4), pp. 1-4.

HeLlmuth Nicholas

1995 All eight ballplayer stelae of Bilbao, Cotzumalhuapa: a complete iconography, FLAAR, Cocoa.

KNAUTH Lothar

1961 «El juego de pelota y el rito de la decapitación », Estudios de Cultura Maya, 1, pp. 183-198, Mexico.

KUBLER George

1969 Studies in Classic Maya iconography, The Connecticut Academy of Arts and Sciences, coll. "Memoirs of the Connecticut Academy of Arts and Sciences » XVIII, New Haven.

LA Fuente Beatriz de

1995 «El arte olmeca », Arqueología Mexicana, II (12), pp. 18-25.

LoEwy Emanuel

1907 The rendering of nature in early Greek art, Duckworth \& Co, London.

Melgar José M.

1869 «Notable escultura antigua », Boletín de la Sociedad Mexicana de Geografía y Estadística, 2, pp. 292-297.

OrR Heather Susan

1997 Power games in the Late Formative valley of Oaxaca: The Ballplayer Carvings at Dainzú, PhD Dissertation, The University of Texas, Austin [unpublished]. 
PARSONS Lee A.

1986 The origins of Maya art: monumental stone sculpture of Kaminaljuyu, Guatemala, and the southern Pacific Coast, Dumbarton Oaks, coll. «Studies in Pre-Columbian Art and Archaeology » 28, Washington.

PASZTORY Esther

2000 "The portrait and the mask: invention and translation », in John E. Clark and Mary E. Pye (eds), Olmec art and archaeology in Mesoamerica, National Gallery of Art, coll. » Studies in the History of Art » 58/coll. « Symposium Papers » 35, Washington, pp. 265-276.

2005 Thinking with things. Toward a new vision of art, University of Texas Press, Austin.

PORTER James B.

1989 «Olmec colossal head as recarved thrones: "mutilation", evolution and recarving », RES, 17-18, pp. 23-29.

ROBERTSON Donald

1974 "Some remarks on stone relief sculpture at Palenque », in Merle Greene Robertson (ed.), Primera Mesa Redonda de Palenque. Part II, Robert Louis Stevenson School, Pebble Beach, pp. 103-108.

SCHELE Linda and Mary Ellen MiLleR

1986 The blood of kings. Dynasty and ritual in Maya art, George Braziller Inc. and Kimball Art museum, New York/Fort Worth.

\section{ScotT John F.}

1978 The danzantes of Monte Albán, 2 vols, Dumbarton Oaks, coll. « Studies in Pre-Columbian Art \& Archaeology »19, Washington.

ScotT Sue

1993 Teotihuacan Mazapan figurines and the Xipe Totec statue. A link between the Basin of Mexico and Oaxaca, Vanderbilt University, Nashville.

2001 The corpus of Terracota figurines from Sigvald Linnés excavations at Teotihuacan, Mexico (1932 \& 1934-1935), and comparative material, The National Museum of Ethnography, coll. « Monograph»18, Stockholm.

SÉJOURNÉ Laurette

1959 Un palacio en la ciudad de los dioses. Exploraciones en Teotihuacan 19551958, INAH, Mexico.

SELER Eduard

1990-1998 Collected works in Mesoamerican linguistics and archaeology, 6 vols, Labyrinthos, Lancaster [1902-1923, Gesammelte abhandlungen zur amerikanischen Sprach- und Alterthumskunde, 6 vols, Berlin].

SPINDEN Herbert J.

1916 «Portraiture in central American art», in Holmes anniversary volume, Harvard University/N. Bryan Press, Peabody Museum of Archaeology and Ethnology, Washington DC, pp. 434-450.

STIRLING Matthew W.

1965 "Monumental sculpture of Southern Veracruz and Tabasco », in Gordon R. Willey (ed.), Handbook of Middle American Indians. Vol. 3. Archaeology 
of Southern Mesoamerica. Part 2, University of Texas Press, Austin, pp. 716-738.

TAUBE Karl

1988 The Albers collection of Pre-Columbian art, Hudson Hills Press, New York.

TAUBE Karl and Marc ZENDER

2009 «American gladiators: ritual boxing in ancient Mesoamerica », in Heather Susan Orr and Rex Koontz (eds), Blood and beauty. Organized violence in the art and archaeology of Mesoamerica and Central America, Cotsen Institute of Archaeology Press, Los Angeles, pp. 161-220.

URCID SERRANO Javier

1993 "The Pacific Coast of Oaxaca and Guerrero: the Western-most extent of Zapotec script », Ancient Mesoamerica, 4, pp. 141-165.

Von WinNING Hasso

1987 La iconografia de Teotihuacan: los dioses y los signos, 2 vols, UNAM, Mexico. 